\title{
The Influence of K-Drama among Youths: A Malaysian Case Study
}

Soo Kum Yoke, Nur Izzah Jamil

To Link this Article: http://dx.doi.org/10.6007/IJARBSS/v12-i1/12111

DOI:10.6007/IJARBSS/v12-i1/12111

Received: 15 November 2021, Revised: 17 December 2021, Accepted: 06 January 2022

Published Online: 24 January 2022

In-Text Citation: (Yoke \& Jamil, 2022)

To Cite this Article: Yoke, S. K., \& Jamil, N. I. (2022). The Influence of K-Drama among Youths: A Malaysian Case Study. International Journal of Academic Research in Business and Social Sciences, 12(1), 1709-1720.

Copyright: (c) 2022 The Author(s)

Published by Human Resource Management Academic Research Society (www.hrmars.com)

This article is published under the Creative Commons Attribution (CC BY 4.0) license. Anyone may reproduce, distribute, translate and create derivative works of this article (for both commercial and non0-commercial purposes), subject to full attribution to the original publication and authors. The full terms of this license may be seen

at: $\underline{\text { http://creativecommons.org/licences/by/4.0/legalcode }}$

Vol. 12, No. 1, 2022, Pg. $1709-1720$

Full Terms \& Conditions of access and use can be found at http://hrmars.com/index.php/pages/detail/publication-ethics 


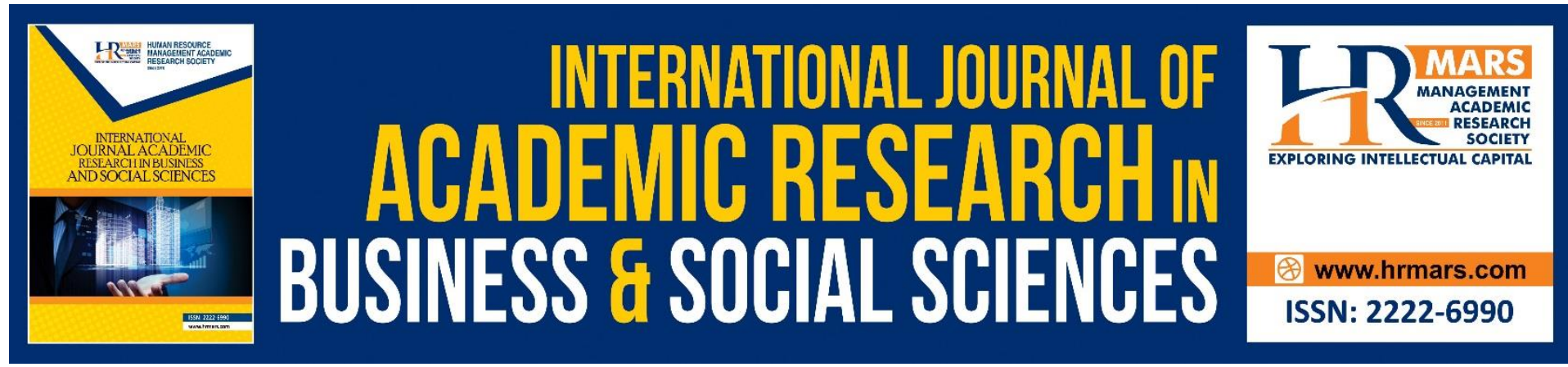

\title{
The Influence of K-Drama among Youths: A Malaysian Case Study
}

\author{
Soo Kum Yoke ${ }^{1}$, Nur Izzah Jamil ${ }^{2}$ \\ ${ }^{1}$ Academy of Language Studies, Universiti Teknologi MARA, Negeri Sembilan Branch, \\ Rembau Campus, 71300 Rembau, Negeri Sembilan, Malaysia, ${ }^{2}$ Faculty of Computer and \\ Mathematical Sciences, Universiti Teknologi MARA, Negeri Sembilan Branch, Rembau \\ Campus, 71300 Rembau, Negeri Sembilan, Malaysia \\ Corresponding Author Email: nurizzah@uitm.edu.my
}

\begin{abstract}
Korean entertainment such as Korean dramas, Korean music and Korean fashion has become increasingly influential worldwide including Malaysia. This study intends to investigate the influence of Korean drama (K-drama) among Malaysian youths in terms of positive and negative influences. As K-dramas become a household name, it is important to find out if there are dangers to its influence and the type of influence it can have on youths today. The study was conducted using a quantitative online survey with a total of 49 respondents and analyzed using descriptive statistics. The results indicated that while there were both positive and negative influences of K-drama watching among Malaysian youths, the positive influence was higher than the negative influence which means that there was more positive influence than negative influence among Malaysian youths. Thus, the study recommends that K-drama watching be watched moderately with action taken to filter and select K-dramas that could influence negatively and endanger the thinking of youths.
\end{abstract}

Keywords: K-wave, K-drama, Positive Influence, Negative Influence, Youths

\section{Introduction}

The Korean entertainment industry or K-wave, notably Hallyu, has become a giant industry represented by good looking actors and actresses, beautiful settings, cultural and moral values and many more. Besides K-pop music, K-drama has also gained popularity in recent years. In effect, K-drama television series has become a favorite pastime in Asia. According to Lee and Yu (2018), picking up from the popularity of K-pop music, K-drama has become influential worldwide. Its effects have become so distinct to the point that K-drama settings and backdrops have provided for travel motivation appeals where tourists are attracted to visit filming locations in South Korea from the K-drama series (Ordoyo et al., 2021).

$\mathrm{K}$-drama has also been found to have influence on Malaysian audiences and researchers also revealed that the impact could be because of the similarities between both cultures in the Asian region (Ariffin et al., 2018). What makes K-drama appealing aside from its storylines, production values, beautiful locations, gorgeous casts, sensational scenes and plots, are the 
familiar traditional issues that the drama deals with such as family values, respect for elders, fighting for true love, and filial duty (Nguyen, 2017).

Youths today are impressionable and addiction to K-drama may have untold consequences. Kim and Ryoo (2007) observed that the K-wave rapid craze in Malaysia has become a phenomenon, developing youths' admiration for Korean culture, language and fashion. Many K-dramas have been adapted throughout the world, achieving notable popularity in some countries including Malaysia. This study is motivated by the need to identify how has Korean drama influenced youths in Malaysia since there is a large number of them who have started consuming more K-dramas on multiple platforms. What are the positive influences of $\mathrm{K}$-drama? And what are the negative influences of $\mathrm{K}$-drama? For those who know too well the emotional stages of K-drama addiction, it is important to investigate the influence of Korean dramas among the younger generation to get an insight into their minds and values.

The popularity of the K-dramas has clearly shown the need for other countries, especially Malaysia to study and better understand how this phenomenon can give any implication to Malaysian youths. Therefore, this study will contribute towards the insight of $\mathrm{K}$-drama influence on youths in Malaysia in terms of positive and negative influences. It will also deliberate if there are any recommendations for youths, parents and society on the whole.

\section{Literature Review}

K-drama has avid viewers all over the world from people from all walks of life. The K-wave phenomenon has reached households like never before in terms of attitude, food, lifestyle, culture, language and values. Lee and $\mathrm{Yu}$ (2018) found that Korean drama (K-drama) is influential in three aspects: theme, production and leading actor or actresses and this finding has potential for increase in Korean Wave contents targeting Chinese consumers. K-dramas which influence Korean Wave contents favorability, viewing motivation and Korean product purchase have hit Chinese audiences besides audiences from across the globe. This is evident in the boom in travel to South Korea to visit site filming locations (Ordoyo et al., 2021). In the Asian region, it owes its popularity to its representation of familiar cultural backgrounds without racial or ethnic stigmatizing that is frequently found in Western movies (Ariffin et al., 2018).

Kim et al (2008) studied the influences of K-pop culture on Hong Kong residents and found that less educated residents were more likely to visit Korea to enjoy Korean culture like tasting Korean food. The study also found that media influence had a significant role in contributing to tourist destination choice of South Korea. A study on K-drama focusing on Korean food showed that the popularity of the TV drama enhanced the national image of Korea and increased interest in Korean tourism in terms of Korean cuisine tourism (Kim et al., 2012). Similarly, Ng and Chan (2019) investigated Korean TV dramas as the determinant of film-induced tourism among young adults in Hong Kong and found that there was a moderate correlation between the characteristics of K-drama and the behavioral intention of travel to these film locations. Further to this, Su et al (2011) examined the ways K-drama affected Taiwanese consumers' attitudes toward the onscreen film locations. The results indicated that there was a relationship between consumers' attitude and film location.

Malaysia has not been exempted from this phenomenon. Malaysia stems from a British colonial history which has largely contributed to exposure to the Western media, but the growing popularity of K-dramas aired on Malaysian television and the ready availability 
of K-drama entertainment on the internet is rapidly changing the scene (Ariffin et al., 2018). Kim and Ryoo (2007) found that the younger generation of Malaysian K-drama viewers have become increasingly influenced by Korean culture, language and fashion. Besides that, it was found that yet another selling point towards the success of $\mathrm{K}$-drama is that it is cheaper to obtain than Japanese or Hong Kong dramas (Ryoo, 2009).

Addiction to anything is usually bad. In Indonesia, it was found that K-drama addiction among youths affected their imitation behavior (Fortunata and Utami, 2021). However, Park et al (2020) found that K-drama could be used to help improve knowledge, attitudes and behaviors on bullying as it engages viewers emotionally with love for the series. In another study, it was found that Korean celebrities had a positive influence on the overall attitude and behavior of viewers as they preach respect for elders, filial duties and family values (Rahmiati, 2012).

Hardly any literature has been found on the positive and negative effects of K-drama towards youths. The majority of research has been focused on the influence of K-drama and K-wave for tourism and consumer attitude towards Korean products. Indeed, many studies attest to how Korean products such as cosmetics, fashion and food have increased in popularity due to the influence of K-drama. Hardly any studies have been found on the influences of K-drama on youths and therefore in the present study, it would be interesting to investigate if K-drama has a positive or negative effect on them.

\section{Methodology}

This study conducts surveys to investigate the influence of K-drama on youths in Malaysia in terms of positive and negative influences. This study focuses on four objectives, which are (1) To investigate the influence of Korean drama among youths, (2) To determine the positive influences of Korean drama among youths, (3) To determine the negative influences of Korean drama among youths and (4) to identify the means scores derived from each factor. In this regard, this section will discuss the methodology applied in terms of the research instrument, sampling technique and data analysis.

\section{Research Instrument}

This study used primary data collected through online questionnaires which are using a Google Form platform, with a total of 19 items. The 19 items were categorized according to 4 parts of Part A - demographics profile, Part B - investigate the influence of Korean drama among Youths, Part $C$ - the positive influences of Korean drama among Youths and part $D$ the negative influences of Korean drama among Youths.

Part A consisted of 4 items while Part B, C and D consisted of 5 items each. The type of questions formulated for Part A was multiple choice, while for Part B, C and D used the Likert Scale type of questions.

\section{Sampling technique and Data Analysis}

An online questionnaire was administered using convenience sampling. Convenience sampling is a type of nonprobability sampling in which respondents have an uneven chance of being selected by random selection procedure. The results from this study provided summaries and conclusions about the sample involved but the results cannot be used to infer to the whole population. Data collected in google form was screened and transferred to SPSS version 26 for analysis. The descriptive statistics were used to attain the objectives of this study. 


\section{Findings \& Discussion}

This section discusses the findings in relations to the objectives of the study. It is divided into demographics of the respondents, the influence of Korean drama among Youths, the positive and negative influences of Korean drama among Youths and the mean scores derived from each factor.

\section{Demographic Analysis}

The survey items were developed with the first 4 items in Part A, demographics of the respondents. The items include gender, location, hours spent watching Korean drama in a week and their favorite drama scene. Table 1 below shows the findings for demographic information of the respondents.

Table 1: demographic information of the respondents.

\begin{tabular}{|l|l|c|c|}
\hline \multicolumn{2}{|l|}{ Demographic } & Frequency & Percentage \\
\hline \multirow{3}{*}{ Gender } & Male & 13 & 26.5 \\
\cline { 2 - 4 } & Female & 36 & 73.5 \\
\hline \multirow{4}{*}{ Location } & Rural & 4 & 8.2 \\
\cline { 2 - 4 } & Suburban & 19 & 38.8 \\
\cline { 2 - 4 } & Urban & 26 & 53.1 \\
\hline \multirow{3}{*}{$\begin{array}{l}\text { Kours spent watching } \\
\text { Korean drama in a week }\end{array}$} & $1-4$ hours & 28 & 57.1 \\
\cline { 2 - 4 } & $5-10$ hours & 18 & 36.7 \\
\cline { 2 - 4 } & More than 10 hours & 3 & 6.1 \\
\hline \multirow{4}{*}{$\begin{array}{l}\text { Favorite Korean drama } \\
\text { scene }\end{array}$} & Adventure & 3 & 6.1 \\
\cline { 2 - 4 } & Crime & 8 & 16.3 \\
\cline { 2 - 4 } & Family drama & 3 & 8.2 \\
\cline { 2 - 4 } & Mystery & 31 & 6.1 \\
\cline { 2 - 4 } & Romantic comedy & 4.3 \\
\hline
\end{tabular}

There were more female respondents (73.5\%) than male respondents (26.5\%). About 57.1 percent of respondents stayed in urban areas, followed by suburban areas $(38.8 \%)$ and only 8.2 percent of respondents were from rural areas. Furthermore, most of the respondents (57.1\%) spent 1 to 4 hours watching Korean drama in a week, 36.7 percent spent 5 to 10 hours watching Korean drama in a week. A small percentage (6.1\%) of respondents spent more than 10 hours watching Korean drama in a week. Majority of the respondents (63.3\%) favored romantic comedy scenes while 8.2 percent favored family drama and 6.1 percent favored mystery scenes. 


\section{The Influence of Korean Drama among Youths}

Based on the first objective of this study which is to investigate the influence of Korean drama among youths, 5 items were developed in Part B of the questionnaire. The items for this part of the study are listed down as follows:

Table 2: The influence of Korean drama among Youths

\begin{tabular}{|l|c|c|c|c|c|}
\hline Items & No interest & $\begin{array}{c}\text { Slightly } \\
\text { interest }\end{array}$ & $\begin{array}{c}\text { Moderately } \\
\text { interest }\end{array}$ & Very interest & $\begin{array}{c}\text { Extremely } \\
\text { interest }\end{array}$ \\
\hline $\begin{array}{l}\text { Your interest } \\
\text { in Korean } \\
\text { drama }\end{array}$ & 2.0 & 2.0 & 14.3 & 24.5 & 57.1 \\
\hline $\begin{array}{l}\text { How do you } \\
\text { like the way } \\
\text { Korean } \\
\text { people dress } \\
\text { and wear } \\
\text { make-up }\end{array}$ & 0.0 & 2.0 & 14.3 & 38.8 & 44.9 \\
\hline $\begin{array}{l}\text { How you like } \\
\text { Korean food } \\
\text { like kimchi, } \\
\text { Korean fried } \\
\text { chicken and } \\
\text { kimbap }\end{array}$ & 0.0 & 2.0 & 22.4 & 34.7 & 40.8 \\
\hline $\begin{array}{l}\text { Your interest } \\
\text { to travel to } \\
\text { Korea for a } \\
\text { visit }\end{array}$ & 0.0 & 0.0 & 12.2 & 24.5 & 63.3 \\
\hline $\begin{array}{l}\text { Your } \\
\text { knowledge of } \\
\text { Korean } \\
\text { culture }\end{array}$ & 2.0 & 12.2 & 38.8 & 32.7 & 14.3 \\
\hline
\end{tabular}

The findings of the study are presented in Table 2 for the influence of Korean drama among youths. It was found that 57.1 percent of the respondent's extremely interested in Korean drama. In fact, most of the respondents preferred the way Korean people dress and wear make-up, very-interest and extremely-interest about 38.8 and 44.9 percent respectively. The findings also showed that 40.8 percent of respondents like Korean food like kimchi, Korean fried chicken and kimbap. Further, 63.3 percent showed their extremelyinterest in traveling to Korean for a visit. However, when asked whether the respondents have knowledge of Korean culture, 38.8 percent showed moderately interest towards Korean culture.

\section{The Positive Influences of Korean Drama}

The second research objective of the study which is to determine the positive influences of Korean drama, 5 items were formulated as listed in the following: 
Table 3: The positive influences of Korean drama among youths

\begin{tabular}{|c|c|c|c|c|c|}
\hline Items & $\begin{array}{l}\text { Strongly } \\
\text { disagree }\end{array}$ & Disagree & Slightly agree & Agree & $\begin{array}{c}\text { Strongly } \\
\text { agree }\end{array}$ \\
\hline $\begin{array}{l}\text { Watching } \\
\text { Korean } \\
\text { drama has } \\
\text { made me } \\
\text { respect and } \\
\text { value my } \\
\text { family }\end{array}$ & 4.1 & 6.1 & 22.4 & 34.7 & 32.7 \\
\hline $\begin{array}{l}\text { Watching } \\
\text { Korean } \\
\text { drama has } \\
\text { broadened } \\
\text { my } \\
\text { knowledge of } \\
\text { other } \\
\text { cultures }\end{array}$ & 2.0 & 2.0 & 12.2 & 51.0 & 32.7 \\
\hline $\begin{array}{l}\text { Watching } \\
\text { Korean } \\
\text { drama can be } \\
\text { quite relaxing } \\
\text { and de- } \\
\text { stressing }\end{array}$ & 4.1 & 0.0 & 10.2 & 28.6 & 57.1 \\
\hline $\begin{array}{l}\text { Watching } \\
\text { Korean } \\
\text { drama has } \\
\text { made me } \\
\text { learn some } \\
\text { Korean } \\
\text { words }\end{array}$ & 4.1 & 6.1 & 16.3 & 32.7 & 40.8 \\
\hline $\begin{array}{l}\text { Watching } \\
\text { Korean } \\
\text { drama has } \\
\text { made me try } \\
\text { eating } \\
\text { Korean food } \\
\text { like kimchi } \\
\text { and kimbap }\end{array}$ & 2.0 & 2.0 & 14.3 & 26.5 & 55.1 \\
\hline
\end{tabular}

Table 3 shows the views of the respondents over the positive influences of Korean drama. From the analysis, it was found that 34.7 percent of the respondents agreed and 32.7 percent strongly agreed that watching Korean drama has made me respect and value my family. The study also found that more than half of respondents $(51 \%)$ agreed that watching Korean drama has broadened their knowledge of other cultures. In addition, 57.1 percent of respondents strongly agreed that watching Korean drama can be quite relaxing and destressing. Further, the respondents strongly agreed (40.8\%) that watching Korean dramas has 
made them learn some Korean words. It was also found that 55.1 percent of the respondents strongly agreed that watching Korean drama has made them try eating Korean food like kimchi and kimbap.

\section{The Negative Influences of Korean Drama}

The third research objective of the study which is to determine the negative influences of Korean drama, 5 items were formulated as listed in the following:

Table 4: The negative influences of Korean drama among Youths

\begin{tabular}{|c|c|c|c|c|c|}
\hline Items & $\begin{array}{l}\text { Strongly } \\
\text { disagree }\end{array}$ & Disagree & Slightly agree & Agree & $\begin{array}{c}\text { Strongly } \\
\text { agree }\end{array}$ \\
\hline $\begin{array}{l}\text { I feel ugly } \\
\text { after } \\
\text { watching the } \\
\text { beautiful } \\
\text { actors and } \\
\text { actresses in } \\
\text { the Korean } \\
\text { drama }\end{array}$ & 12.2 & 14.3 & 36.7 & 16.3 & 20.4 \\
\hline $\begin{array}{l}\text { I become } \\
\text { addicted to } \\
\text { watching } \\
\text { Korean } \\
\text { drama and } \\
\text { will spend } \\
\text { hours } \\
\text { watching it }\end{array}$ & 8.2 & 8.2 & 24.5 & 12.2 & 46.9 \\
\hline $\begin{array}{l}\text { I think I am } \\
\text { influenced to } \\
\text { buy Korean } \\
\text { cosmetics } \\
\text { and clothes } \\
\text { to follow the } \\
\text { Korean } \\
\text { fashion }\end{array}$ & 8.2 & 6.1 & 22.4 & 28.6 & 34.7 \\
\hline $\begin{array}{l}\text { I think the } \\
\text { love scenes } \\
\text { like kissing } \\
\text { and bed } \\
\text { scenes are } \\
\text { quite open } \\
\text { and can have } \\
\text { a negative } \\
\text { impact on } \\
\text { Youths }\end{array}$ & 6.1 & 18.4 & 28.6 & 26.5 & 20.4 \\
\hline $\begin{array}{l}\text { Watching } \\
\text { Korean }\end{array}$ & 34.7 & 12.2 & 26.5 & 10.2 & 16.3 \\
\hline
\end{tabular}




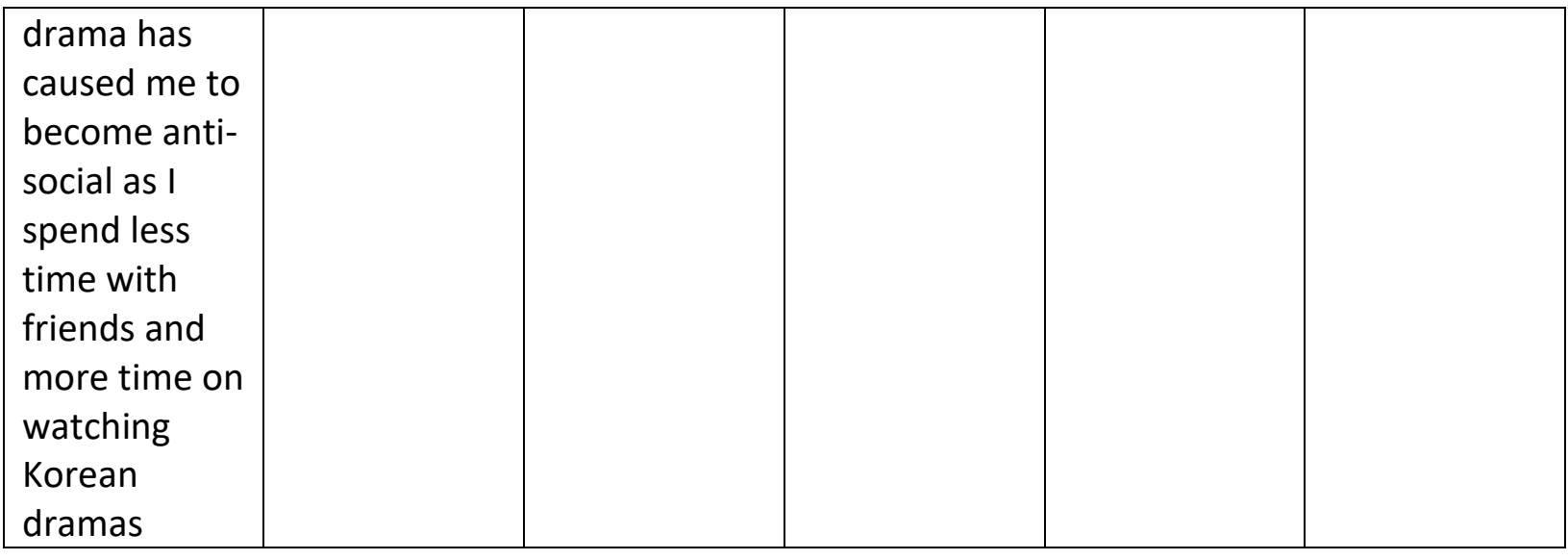

Table 4 shows the views of the respondents over the negative influences of Korean drama. The findings found that most of them (36.7\%) slightly agreed that they feel ugly after watching the beautiful actors and actresses in the Korean drama. This study also shows 46.9 percent strongly agreed to become addicted to watching Korean drama and will spend hours watching it. Moreover, 34.7 percent think that they were influenced to buy Korean cosmetics and clothes to follow the Korean fashion. However, the respondents slightly agreed (28.6\%) when asked about love scenes like kissing and bed scenes are quite open and can have a negative impact on youths. It was also found that about 34.7 percent strongly disagreed that watching Korean drama has caused them to become anti-social as they spend less time with friends and more time on watching Korean dramas.

\section{Mean Scores}

Mean score was used to describe the scores derived from Likert type scales reported. Respondents were asked to rate their degree of agreement on a scale ranging from 1 to 5 , with 1 suggesting strong disagreement to 5 indicating strong agreement. Table 5 reported the mean score of the influence of Korean drama among youths, positive influence of Korean drama among youths and negative influence of Korean drama among youths.

The mean score of the influence of Korean drama among youths is 4.14 with a standard deviation of 0.66 . The skewness value also showed that the distribution is skewed to the left (-0.968) indicating where most of the data clustered around the strong agreement. It can be said that most of the respondents are interested in K-dramas.

Furthermore, the mean score of positive influence of Korean drama reported 4.12 with a standard deviation of 0.83 . The skewness value also showed that the distribution is highly skewed to the left (-1.643) indicating that most of the data clustered around the strong agreement. However, the mean score of negative influence of Korean drama among Youths is 3.35 indicates the moderate agreement with a standard deviation of 0.90 . The skewness value was also close to zero, which showed that the distribution is slightly skewed to the left $(-0.068)$ indicates most of data clustered to almost normally distributed. This also supported the mean value of 3.35 where the agreement is only at moderate agreement. Thus, it can be said that K-drama influence is more positive than negative to Malaysian youths. While there are both positive and negative influences, it was found that the respondents' perception of positive influences were higher than the negative influences. 
Table 5: Mean analysis of Korean drama among youths

\begin{tabular}{|l|c|c|c|}
\hline Factors & Mean & $\begin{array}{c}\text { Standard } \\
\text { Deviation }\end{array}$ & $\begin{array}{c}\text { Skewnes } \\
\text { s }\end{array}$ \\
\hline The influence of Korean drama among youths & 4.14 & 0.66 & -0.968 \\
\hline Positive influence of Korean drama among youths & 4.12 & 0.83 & -1.643 \\
\hline Negative influence of Korean drama among youths & 3.35 & 0.90 & -0.068 \\
\hline
\end{tabular}

\section{Conclusion}

This study has attempted to provide a case study review of Malaysian youths' influence of Kdrama based on the current popularity of K-wave and the increasing number of Malaysian fans who are influenced by Korean culture, language and fashion. The findings have given some insights on youths' views and responses to the influence of K-drama in particular, the positive influences of K-drama and the negative influences of K-drama. The purpose was to see if there are any implications and recommendations for youths, parents and society as a whole.

From the findings, it can be concluded that most of the respondents are interested in K-dramas. It was also found that most of them liked Korean dressing and make-up as well as Korean food like kimchi, Korean fried chicken and kimbap. Majority of the respondents were either extremely interested, interested or moderately interested in traveling to Korea. They were mostly moderately knowledgeable and knowledgeable of Korean culture. This shows that most of the respondents are interested in or influenced by K-drama in terms of dressing and make-up, food, Korean culture and have interest in traveling to Korea.

In terms of the positive influence of K-drama, majority of the respondents either agree or strongly agree that watching Korean dramas have made them respect and value their families. Majority of the respondents also either agree or strongly agree that watching Korean drama has broadened their knowledge of other cultures. Furthermore, most of the respondents found that watching Korean drama can be quite relaxing and de-stressing, watching Korean drama has made them learn some Korean words and watching Korean drama has made them try eating Korean food like kimchi and kimbap. The findings are similar to previous studies where K-drama was found to help improve knowledge, attitudes and behaviors on bullying (Park et al., 2020) and promote respect for elders, filial duties and family values (Rahmiati, 2012).

In terms of the negative influence of K-drama, more than half the respondents either slightly agree, agree or strongly agree that they feel ugly after watching the beautiful actors and actresses in the Korean drama. Majority of the respondents also slightly agree, agree, or strongly agree that they have become addicted to watching Korean drama and will spend hours watching it. In addition, most of the respondents also slightly agree, agree, or strongly agree that they are influenced to buy Korean cosmetics and clothes to follow the Korean fashion and that the love scenes like kissing and bed scenes are quite open and can have a negative impact on youths. However, the majority of the respondents strongly disagreed or disagreed that watching Korean dramas has caused them to become anti-social as they spend less time with friends and more time on watching Korean dramas.

From the mean score analysis, it can also be deduced that $\mathrm{K}$-drama influence is more positive than negative to Malaysian youths. While there are both positive and negative 
influences, it was found that the respondents' perception of positive influences were higher than the negative influences. Thus, it can be concluded that Malaysian youths are influenced by K-drama and the influences are both positive and negative. It was interesting to note that they disagreed that watching K-dramas caused them to become anti-social. Korean dramas had positive influence in terms of food and culture, attitudes and behavior but at the same time this could lead to addiction to K-dramas, feelings of being ugly and excessive shopping for Korean cosmetics and clothes. Hence, for entertainment purposes, learning of a new culture, learning of a new language and relaxation, a moderate watching of K-drama is recommended.

The main contribution of this study is where the selection of K-drama watching should be done to ensure that negative influences are avoided. The government should also filter Korean dramas so that negative influences do not seep into society. Parents could decide to limit the content and be more stringent by means of parental controls for content viewing and manage their children for screen time. Nonetheless, this study highlighted that K-drama had more positive influence than negative influence on Malaysian youths.

\section{References}

Ordoyo, A. F. P., Menor, J. C. V., Felecia, M. L. D. (2021). A Case Study on the Effect of K-Drama in Choosing South Korea as a Travel Destination. International Journal of Sciences: Basic and Applied Research (IJSBAR) Volume 58, No. 2, pp 19-42.

Lee, J. H., and Yu, S. Y. (2018). The Influence of the Aspects of K-drama on the Favourability of Korean Wave Contents, Viewing Motivation and Purchasing Intention of Korean Products: Targeting Chinese Consumers. International Journal of Pure and Applied Mathematics Vol.118 (19), pp. 429-443.

Ariffin, T. J., Abu Bakar, H., and Yusof, N. H. (2018). Culture in Korean Drama towards Influencing Malaysian Audiences. International Journal of Innovative Research in Engineering \& Management (IJIREM) V.5(1). DOI:10.21276/ijirem.2018.5.1.3.

Nguyen, T. T. (2017). Association between watching Korean Dramas and Single Vietnamese women's relationship satisfaction and commitment: An interpretation using Cultivation Theory. A thesis submitted to the Graduate Division of the University of Hawaii at Manoa in partial fulfillment of the requirements for the degree of Master of Arts in Communication.

Kim, E. M., \& Ryoo, J. (2007). South Korean Culture Goes Global: K-Pop and the Korean Wave. Korean Social Science Journal, 34(1), 117-147.

Ryoo, W. (2009). Globalization, or the logic of cultural hybridization: The case of the Korean wave. Asian Journal of Communication, 19(2), 137-151.

Rahmiati, L. (2012). The Impact of Korean Wave to the Acceptance of Korean Culture and Product among Indonesian. Thesis submitted to the KDI School of Public Policy and Management in partial fulfillment of the requirements for the degree of Master of Public Policy.

Fortunata, F., and Utami, L. S. S. (2021). The Effect of Addiction of Watching Korean Drama Series on Imitation Behavior of Adolescents. Advances in Social Science, Education and Humanities Research, Vol.570

Kim, S. S., Agrusa, J., Chon, K., \& Cho, Y. (2008) The Effects of Korean Pop Culture on Hong Kong Residents' Perceptions of Korea as a Potential Tourist Destination. Journal of Travel \& Tourism Marketing, 24:2-3, 163-183, DOI: 10.1080/10548400802092684 
Kim, S., Kim, M., Agrusa, J., and Lee, A. (2012) Does a Food-themed TV Drama Affect Perceptions of National Image and Intention to Visit a Country? An Empirical Study of Korean TV Drama. Journal of Travel \& Tourism Marketing, 29:4, 313-326, DOI: 10.1080/10548408.2012.674869

Su, H. J., Huang,Y ., Brodowsky, G., and Kim,H. J. (2011). The impact of product placement on TV-induced tourism: Korean TV dramas and Taiwanese viewers, Tourism Management, Vol. $\quad 32(4), \quad$ pp. $805-814, \quad$ ISSN 02615177,https://doi.org/10.1016/j.tourman.2010.06.020. 